\title{
A Tentative Analysis of the De-globalization Trend -- Taking USA as an Example
}

\author{
Wanning Wang \\ Tsinghua University, Beijing, China. \\ wwn15@mails.tsinghua.edu.cn
}

\begin{abstract}
Currently, the de-globalization trend is more and more obvious led by some western countries. The reverse globalization tendency are not only demonstrated in the field of economy but also developed in the area of party behavior and government behavior. As a result, the idea of populism in these countries is prevailing, especially in the America. Since Trump was elected as the president, the behaviors that are against globalization have caused a large number of disputes and discussions, such as the trade protectionism policy, anti-immigration policy and the proclamation to withdraw from international organizations. This article will talk about the main reasons of what is happening now in today's world.
\end{abstract}

Keywords: De-globalization; trade protectionism; anti-immigration; global governance.

\section{浅谈逆全球化趋势-一以美国为例}

\author{
王莞宁 \\ 清华大学, 北京, 中国
}

摘 要: 当前, 以西方国家为首的逆全球化浪潮越来越明显。资本主义大国的逆全球化突破了 经济行为, 而发展成为政党行为、国家和政府的行为, 实施一系列逆转经济全球化的措施, 排斥外来民族，民粹主义思潮兴起。[1]其中，美国的逆全球化特征最为明显，产生的全球影 响最大。本文将以美国为例, 通过了解美国贸易保护主义、反移民政策以及宣称退出相关国 际组织等政策, 分析此次逆全球化潮流出现的原因。

关键词：逆全球化；贸易保护主义；反移民政策；全球治理

\section{1. 前言}

在美国开启 “特朗普时代”之后，特朗普的执政核心是 “一切以美国利益为先”，以此为宗 旨试图在全球进行利益的再分配。因此, 无论是就业、产业、贸易、能源还是外交政策都在 试图重构全球秩序与格局。[2]这不仅预示着全球层面由此引发一场经济结构的再造, 而且意 味着全球将不得不面对以强硬的保护主义和资源要素流动壁垒为特征的逆全球化的冲击。 探求这一趋势出现以及发展的原因以及影响有助于帮助我们更好地应对这一变局, 了解全球 化发展的大方向，具备全球的战略眼光。

\section{2. 产生原因}

\section{1. 金融危机后的经济环境}

近4、5年来，美国经济从经济危机中缓慢复苏，然而美国经济增长不够强劲，经济增速维持 在较低的水平，并呈现下降趋势。2008 年下半年金融危机后，2009 年美国经济增速为-2. $04 \%$ 。 


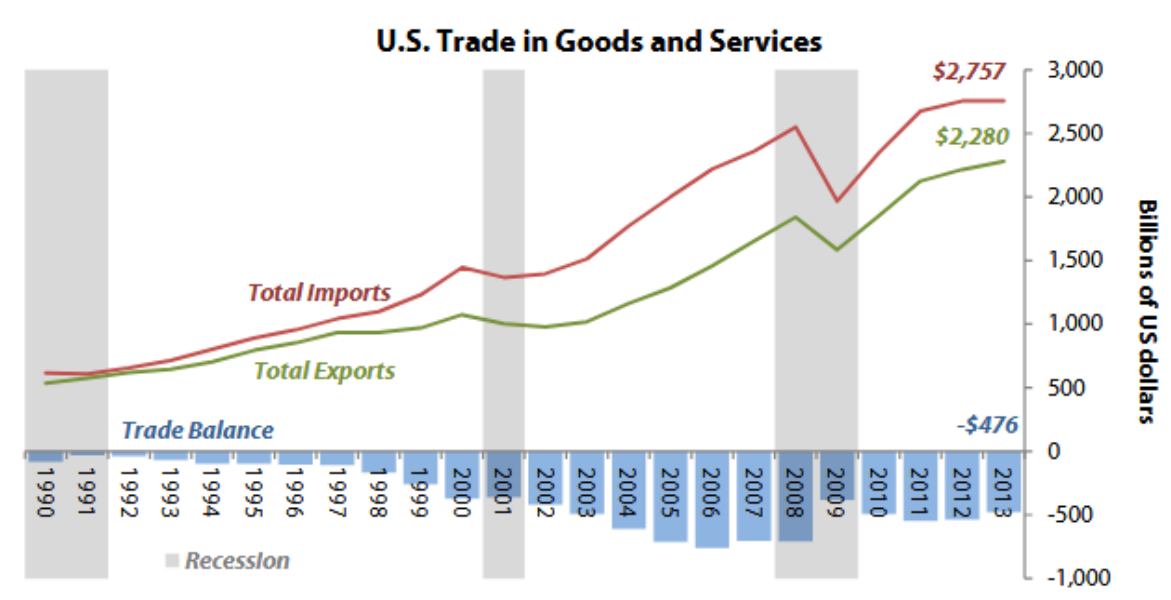

图1：美国1990年以来商品和服务贸易量

（图表来源于美国商务部网站）

而从美国贸易来看, 在长期美国一直都是进口量大于出口量, 贸易赤字在金融危机之前日趋 加大。为了寻求新的经济增长点, 增加经济产出之前, 必然要先寻找市场需求, 实行贸易保 护主义成了必然的政策选择。[5]全球市场需求不足, 各国必然会首先寻求国内市场, 逆全球 化和贸易保护主义的思潮开始兴起。[2]

因此对于美国来说, 在全球贸易环境相对疲软的情况下, 为了追求美国的经济增长, 就必须 要更多的激发本国市场的动力和活力。因此就必须要在一定程度上削减进口产品量, 由此形 成了逆全球化的浪潮和趋势。

\section{2. 美国国内产业空心化以及失业}

自由贸易的缺陷使许多美国人的利益受到损害，从而招致他们的反对。研究表明，美国的部 分产业, 特别是制造业确实受到自由贸易的冲击。假如平均到每个美国工人身上的中国进口 额提高 1000 美元, 当地的就业人数将会减少 $0.6 \%$ (制造业减少 $0.18 \%$ ), 失业率将上升 $0.22 \%$ ， 劳动参与率将下降 $0.55 \%$, 而且教育程度更低、收入更少的工人受到的冲击更大。 [6]在过 去几十年的快速全球化中, 最大的受益者是发展中国家的中上阶层和发达国家的高收入群体, 而最大的受损者却是发达国家的中低收入群体。

对于美国而言, 由于金融资本主义的盛行, 金融业创造的 GDP 占美国 GDP 的比重已经与制造 业不相上下, 产业空心化也越来越引起美国人的重视, 为遏制去工业化的趋势, 贸易保护措 施也层出不穷。

\section{3. 移民给美国带来的不利影响}

美国的逆全球化另一个重要表现在于对于移民的限制。

必须承认，外来移民确实会给国家带来许许多多难以预测和估量的影响。外来移民可能冲击 国内劳动力市场, 加剧竞争, 拉低工资, 导致失业。虽然总体来说移民对美国的就业市场没 有明显的负面影响, 因为这些移民多从事本土居民不愿意干的低技能工作，但在经济衰退时 本土居民容易将自身失业问题归处于移民。同时, 有研究表明, 移民对低学历的本土就业者 的工资会产生一定的负面影响, 大约使其降低了 4. 7\%。[7]其次, 外来移民可能引发本土居民 心理失衡, 产生相对被剥夺感, 进而激发本土主义和种族歧视。反对移民的美国人特别反感 移民占用他们的福利资源, 他们认为那些移民是插队者和懒惰者, 以牺牲底层白人利益为代 价而得到社会优待, 并认为民主党在此问题上起了推波助澜的作用。[8]再次, 外来移民可能 导致过度的社会多元化, 引发国家认同危机。最后, 外来移民还可能带来更多的犯罪活动和 安全威胁。特朗普即以此为由要求限制墨西哥移民和穆斯林移民进入美国。[3] 


\section{4. 全球治理体系滞后}

当前全球治理体系和各国宏观政策协调机制与全球化的发展不相适应，也是导致逆全球化现 象的主要原因之一。现行全球治理体系形成于二战后, 已难以适应世界政治经济社会快速变 化的新形势发展需要。全球化发展要求加强全球治理和全球监管协调, 然而, 各国经济政策 协调难度加大，滞后于全球化的发展。[4]

对于美国来说，伴随其在全球相对实力的下降，其在全球治理体系中的地位越来越受到新兴 国家, 比如中国的挑战, 因此, 美国也越来越觉得在一些国际组织以及国际条约中的利益受 到了削弱, 并且越来越多地抱怨国际组织的问题。事实上, 现在的国际组织都没有超越国家 主权的力量, 也难以在各个国家之间周旋, 达到一个比较理想的利益平衡。在特朗普执政后, 他开始梳理美国在各个贸易组织中的得失, 并作出了相应的举措, 包括退出以及重新修约等 等, 对于全球化、全球治理体系来说是一个不小的阻碍和挑战, 不仅影响了全球经济全球化, 也影响了国际政治的走向。

\section{3. 结论}

逆全球化实质上是资本主义社会矛盾、阶级矛盾激化的产物; 是国际金融垄断资本主导的全 球化、金融化发展模式的危机; 是资本主义国家转移国内广大民众与少数金融资本利益集团 之间矛盾的结果。[1]逆全球化升温、贸易保护主义抬头等增加了许多新的不确定性变量, 全 球经济受此影响或仍将维持低增长和弱复苏态势。

\section{References}

[1]. Luan WenLian. The critical analysis of the anti-globalization and de-globalization in western countries [J]. (in Chinese) Marxist Study, 2018(04):89-97.

[2]. Hu Jinxing. The study of the economic logic behind the de-globalization and the trade protectionism (in Chinese) [J]. Reform of the economic system, 2017 (06): 19-26.

[3]. Fu Suiting. The revive of de-globalization, populism and nationalism in the U.S.A (in Chinese) [J]. International Relationship, 2017 (05): 34-46+ 152-153.

[4]. Zhang Mona. The current trend of de-globalization and the new direction of globalization (in Chinese) [J]. Macroeconomic management, 2017 (05):33-37.

[5]. Li Yang and Huang Yandi, the competition of Chinese and American international trade policy-based on the perspective of the provision of international public products (in Chinese) [J]. Global economics and politics, 2016, (10): 114- 136, 159- 160.

[6]. David H. Author, David Dorn and Gordon H. Hanson, "The China syndrome: Local Labour Market Effects of Import Competition in the United States, "American Economic Review, and Vol. 103, No.6, 2013, p. 2143.

[7]. George J. Boreas and Lawrence F. Katz, "The Evolution of the Mexican-Born Workforce in the United States, "in George J. Boreas, ed. Mexican Immigration to the United States, University of Chicago Press, 2007, pp. 13 15.

[8]. Arlie Russell Hoch child, Strangers in Their Own Land: Anger and Mourning on the American Right, New York: The New Press, 2016, pp. 137 139. 